\title{
A superior Ce-W-Ti mixed oxide catalyst for the selective catalytic reduction of $\mathrm{NO}_{x}$ with $\mathrm{NH}_{3}$
}

\author{
Wenpo Shan ${ }^{\mathrm{a}, \mathrm{b}}$, Fudong Liu ${ }^{\mathrm{a}, *}$, Hong He ${ }^{\mathrm{a}, *}$, Xiaoyan Shi ${ }^{\mathrm{a}}$, Changbin Zhang ${ }^{\mathrm{a}}$ \\ ${ }^{a}$ Research Center for Eco-Environmental Sciences, Chinese Academy of Sciences, Beijing 100085, PR China \\ ${ }^{\mathrm{b}}$ College of Chemistry and Environmental Science, Hebei University, Baoding 071002, PR China
}

\section{A R T I C L E I N F O}

\section{Article history:}

Received 30 July 2011

Received in revised form

13 December 2011

Accepted 15 December 2011

Available online 23 December 2011

\section{Keywords:}

Ce-W-Ti mixed oxide

SCR

Nitrogen oxides

Homogeneous precipitation method

Diesel engine exhaust

\begin{abstract}
A B S T R A C T
A superior Ce-W-Ti mixed oxide catalyst prepared by a facile homogeneous precipitation method showed excellent $\mathrm{NH}_{3}-\mathrm{SCR}$ activity and $100 \% \mathrm{~N}_{2}$ selectivity with broad operation temperature window and extremely high resistance to space velocity, which is a very promising catalyst for $\mathrm{NO}_{x}$ abatement from diesel engine exhaust. The excellent catalytic performance is associated with the highly dispersed active $\mathrm{Ce}$ and promotive $\mathrm{W}$ species on $\mathrm{TiO}_{2}$. The introduction of $\mathrm{W}$ species could increase the amount of active sites, oxygen vacancies, and Brønsted and Lewis acid sites over the catalyst, which is also beneficial to improve the low temperature activity by facilitating "fast SCR" reaction and enhance both of the high temperature activity and $\mathrm{N}_{2}$ selectivity simultaneously by inhibiting the unselective oxidation of $\mathrm{NH}_{3}$ at high temperatures.
\end{abstract}

(C) 2011 Elsevier B.V. All rights reserved.

\section{Introduction}

With the rising challenges from energy crisis and global warming, diesel engines become more and more competitive due to its high fuel efficiency. However, the removal of $\mathrm{NO}_{x}$ from diesel engine exhaust, under oxygen-rich conditions, remains one of the major challenges in environmental catalysis [1,2].

Selective catalytic reduction of $\mathrm{NO}_{x}$ with $\mathrm{NH}_{3}\left(\mathrm{NH}_{3}-\mathrm{SCR}\right)$, using $\mathrm{V}_{2} \mathrm{O}_{5}-\mathrm{WO}_{3} / \mathrm{TiO}_{2}$ or $\mathrm{V}_{2} \mathrm{O}_{5}-\mathrm{MoO}_{3} / \mathrm{TiO}_{2}$ as catalyst, has been widely used for the removal of $\mathrm{NO}_{x}$ from stationary sources. This technology is also introduced into the market for diesel vehicles and is thought to be one of the best technologies for meeting the severe $\mathrm{NO}_{x}$ reduction goals $[1,3]$. However, the toxicity of active vanadium species together with the narrow operation temperature window restrained the practical applications of the V-based catalysts for diesel vehicles. Some other transition metal-based oxide catalysts (such as $\mathrm{Fe}, \mathrm{Cu}, \mathrm{Mn}$ and $\mathrm{Ce}$ ) were reported as potential substitutions of V-based catalyst for diesel vehicles [4-7]. Nevertheless, these catalysts were mainly tested under relatively low GHSV below $100,000 \mathrm{~h}^{-1}$ using sieved powders, and some of them also suffer from low $\mathrm{N}_{2}$ selectivity $[5,6]$.

\footnotetext{
* Corresponding authors at: P.O. Box 2871, 18 Shuangqing Road, Haidian District, Beijing 100085, PR China. Tel.: +86 10 62849123; fax: +86 1062849123.

E-mail addresses: fdliu@rcees.ac.cn (F. Liu), honghe@rcees.ac.cn (H. He).
}

The reduction of $\mathrm{NH}_{3}-\mathrm{SCR}$ catalyst volume is one of the main challenges of diesel vehicle with limited space on board [1]. Therefore, $\mathrm{Fe}$ (or $\mathrm{Cu}$ )-exchanged zeolites, especially ZSM-5, have received much attention due to their superior $\mathrm{NH}_{3}-\mathrm{SCR}$ activity under high GHSV [8-12]. However, the insufficient low-temperature activity of Fe-ZSM-5 and the poor hydrothermal stability of Cu-ZSM-5 are neither satisfactorily solved [8]. Recently, some Cu-containing small-pore zeolites, such as Cu-SSZ-13 and Cu-SAPO-34, have been discovered as $\mathrm{NH}_{3}$-SCR catalysts with excellent catalytic activity even after severe hydrothermal aging [13-15]. There are continuing efforts to develop new $\mathrm{NH}_{3}-\mathrm{SCR}$ catalysts for controlling the $\mathrm{NO}_{x}$ emission from diesel engines.

In our previous study, we have developed a promising $\mathrm{Ce} / \mathrm{TiO}_{2}$ catalyst prepared by impregnation method showing high SCR activity at $275-400{ }^{\circ} \mathrm{C}$ [16]. Afterwards, Gao et al. [17] compared the $\mathrm{NH}_{3}$-SCR activity of $\mathrm{CeO}_{2} / \mathrm{TiO}_{2}$ catalysts prepared by three methods, and they found that the catalyst prepared by single step sol-gel method shows higher activity than that prepared by impregnation method due to better dispersion of active nano-crystalline ceria. $\mathrm{WO}_{3}$ was used as stabilizer and promoter of the traditional $\mathrm{V}_{2} \mathrm{O}_{5}$ $\mathrm{WO}_{3} / \mathrm{TiO}_{2}$ catalyst for many years $[18,19]$. Chen et al. [20] found that addition of $\mathrm{W}$ could enhance the activity of $\mathrm{CeO}_{2} / \mathrm{TiO}_{2}$ catalyst prepared by co-impregnation method. However, in their work the catalytic activity was measured mainly under a relatively low GHSV of $28,000 \mathrm{~h}^{-1}$, and the $\mathrm{NO}_{x}$ conversion of the catalyst dramatically decreased at higher GHSV. Recently, we reported a remarkable improvement of $\mathrm{Ce}-\mathrm{Ti}$ based catalyst, with highly dispersed $\mathrm{CeO}_{2}$ 
on $\mathrm{TiO}_{2}$, prepared by a facile homogeneous precipitation method. This Ce-Ti mixed oxide catalyst presented prominent performance even under a high GHSV of $150,000 \mathrm{~h}^{-1}$ [21].

In this study, after further optimization of the homogeneous precipitation method, the prepared Ce-Ti mixed oxide powder catalyst $\left(\mathrm{Ce}_{0.2} \mathrm{TiO}_{x}\right)$ exhibited rather good activity under a high GHSV of $250,000 \mathrm{~h}^{-1}$ (equal to about $25,000 \mathrm{~h}^{-1}$ for a monolith catalyst). More importantly, a W doped Ce-Ti mixed oxide $\left(\mathrm{Ce}_{0.2} \mathrm{~W}_{0.2} \mathrm{TiO}_{x}\right)$ powder catalyst present excellent $\mathrm{NH}_{3}$-SCR activity together with $100 \% \mathrm{~N}_{2}$ selectivity in a broad temperature range even under an extremely high GHSV of $500,000 \mathrm{~h}^{-1}$ (equal to about $50,000 \mathrm{~h}^{-1}$ for a monolith catalyst), which is a promising catalyst for $\mathrm{NO}_{x}$ abatement from diesel engine exhaust.

\section{Experimental}

\subsection{Catalyst synthesis and activity test}

The Ce-Ti mixed oxide catalyst, with a Ce/Ti molar ratio of 0.2 , was denoted as $\mathrm{Ce}_{0.2} \mathrm{TiO}_{x}$. The transition metal doped catalysts were denoted as $\mathrm{Ce}_{0.2} \mathrm{M}_{0.1} \mathrm{TiO}_{x}(\mathrm{M}=\mathrm{W}$, Mo, Fe, Co, Cu; M/Ti molar ratio $=0.1$ ) and $\mathrm{Ce}_{0.2} \mathrm{~W}_{\mathrm{a}} \mathrm{TiO}_{x}$ ( " $a$ " represents the $\mathrm{W} / \mathrm{Ti}$ molar ratio; $a=0.1,0.2,0.3,0.5)$. The catalysts were all prepared by the optimized homogeneous precipitation method. The aqueous solutions of $\mathrm{Ce}\left(\mathrm{NO}_{3}\right)_{3} \cdot 6 \mathrm{H}_{2} \mathrm{O}, \mathrm{Ti}\left(\mathrm{SO}_{4}\right)_{2}$ and relevant transition metal precursor $\left(\left(\mathrm{NH}_{4}\right)_{10} \mathrm{~W}_{12} \mathrm{O}_{41},\left(\mathrm{NH}_{4}\right)_{6} \mathrm{Mo}_{7} \mathrm{O}_{24} \cdot 4 \mathrm{H}_{2} \mathrm{O}, \mathrm{Fe}\left(\mathrm{NO}_{3}\right)_{3} \cdot 9 \mathrm{H}_{2} \mathrm{O}\right.$, $\mathrm{Co}\left(\mathrm{NO}_{3}\right)_{2} \cdot 6 \mathrm{H}_{2} \mathrm{O}$, or $\left.\mathrm{Cu}\left(\mathrm{NO}_{3}\right)_{2} \cdot 3 \mathrm{H}_{2} \mathrm{O}\right)$ were mixed with required molar ratios $\left(\mathrm{H}_{2} \mathrm{C}_{2} \mathrm{O}_{4} \cdot 2 \mathrm{H}_{2} \mathrm{O}\right.$ was used to facilitate the solution of $\left(\mathrm{NH}_{4}\right)_{10} \mathrm{~W}_{12} \mathrm{O}_{41}$ and $\left.\left(\mathrm{NH}_{4}\right)_{6} \mathrm{Mo}_{7} \mathrm{O}_{24} \cdot 4 \mathrm{H}_{2} \mathrm{O}\right)$. Excessive urea aqueous solution was then added into the mixed solution. The solution was heated to $90^{\circ} \mathrm{C}$ and held there for $12 \mathrm{~h}$ under vigorous stir. After filtration and washing with deionized water, the resulting precipitant was dried at $100^{\circ} \mathrm{C}$ overnight and subsequently calcined at $500^{\circ} \mathrm{C}$ for $5 \mathrm{~h}$ in air condition. Before $\mathrm{NH}_{3}$-SCR activity test, the powder catalysts were pressed, crushed and sieved to 40-60 mesh.

The SCR activity tests of the sieved powder catalysts were carried out in a fixed-bed quartz flow reactor at atmospheric pressure. The reaction conditions were controlled as follows: $500 \mathrm{ppm}$ NO (or $250 \mathrm{ppm} \mathrm{NO}$ and $250 \mathrm{ppm} \mathrm{NO} \mathrm{NO}_{2}$ ), $500 \mathrm{ppm} \mathrm{NH}_{3}, 5$ vol.\% $\mathrm{O}_{2}, 5$ vol.\% $\mathrm{CO}_{2}$ (when used), 5 vol.\% $\mathrm{H}_{2} \mathrm{O}$ (when used), $100 \mathrm{ppm} \mathrm{SO}$ (when used), balance $\mathrm{N}_{2}$, and $500 \mathrm{ml} / \mathrm{min}$ total flow rate. Different GHSV were obtained by changing the volume of catalyst. The effluent gas, including $\mathrm{NO}, \mathrm{NH}_{3}, \mathrm{NO}_{2}$ and $\mathrm{N}_{2} \mathrm{O}$ was continuously analyzed by an online NEXUS 670-FTIR spectrometer equipped with a gas cell with $0.2 \mathrm{dm}^{3}$ volume. The FTIR spectra were collected after $1 \mathrm{~h}$ when the SCR reaction reached a steady state, and the $\mathrm{NO}_{x}$ conversion and $\mathrm{N}_{2}$ selectivity were calculated accordingly $[6,21]$.

$\mathrm{NO}_{x}$ conversion $=\left(1-\frac{[\mathrm{NO}]_{\text {out }}+\left[\mathrm{NO}_{2}\right]_{\text {out }}}{[\mathrm{NO}]_{\text {in }}+\left[\mathrm{NO}_{2}\right]_{\text {in }}}\right) \times 100 \%$

$\mathrm{N}_{2}$ selectivity $=\frac{[\mathrm{NO}]_{\text {in }}+\left[\mathrm{NH}_{3}\right]_{\text {in }}-\left[\mathrm{NO}_{2}\right]_{\text {out }}-2\left[\mathrm{~N}_{2} \mathrm{O}\right]_{\text {out }}}{[\mathrm{NO}]_{\text {in }}+\left[\mathrm{NH}_{3}\right]_{\text {in }}} \times 100 \%$

\subsection{Characterizations}

The surface areas of the catalysts were obtained from $\mathrm{N}_{2}$ adsorption/desorption analysis at $77 \mathrm{~K}$ using a Quantachrome Quadrasorb SI-MP. Prior to the $\mathrm{N}_{2}$ physisorption, the catalysts were degassed at $300^{\circ} \mathrm{C}$ for $4 \mathrm{~h}$. Surface areas were determined by BET equation in 0.05-0.35 partial pressure range.

Powder X-ray diffraction (XRD) measurements of the catalysts were carried out on a computerized PANalytical X'Pert Pro diffractometer with $\mathrm{Cu} K \alpha(\lambda=0.15406 \mathrm{~nm})$ radiation. The data of
$2 \theta$ from $20^{\circ}$ to $80^{\circ}$ were collected at $8^{\circ} / \mathrm{min}$ with the step size of $0.07^{\circ}$.

Visible Raman spectra of the catalysts were collected at room temperature on a Spex $1877 \mathrm{D}$ triplemate spectrograph with spectral resolution of $2 \mathrm{~cm}^{-1}$. A $532 \mathrm{~nm}$ DPSS diode-pump solid semiconductor laser was used as the excitation source and the power output was about $40 \mathrm{~mW}$. Before measurements, the samples were well ground and mounted into a spinning holder to avoid thermal damage during the scanning. The Raman signals were collected with conventional $90^{\circ}$ geometry and the time for recording each spectrum was about 30 s. All Raman spectra used in the paper were original and unsmoothed.

The XPS of $\mathrm{Ce}_{0.2} \mathrm{TiO}_{x}$ and $\mathrm{Ce}_{0.2} \mathrm{~W}_{0.2} \mathrm{TiO}_{x}$ were both recorded on a Scanning X-ray Microprobe (Axis Ultra, Kratos Analytical Ltd.) using $\mathrm{Al} \mathrm{K} \alpha$ radiation (1486.7 eV). Binding energies of Ce 3d, Ti 2p and O $1 \mathrm{~s}$ were calibrated using $\mathrm{C} 1 \mathrm{~s}$ peak $(\mathrm{BE}=284.8 \mathrm{eV})$ as standard.

The in situ DRIFTS experiments were performed on an FTIR spectrometer (Nicolet Nexus 670) equipped with a smart collector and an MCT/A detector cooled by liquid nitrogen. The reaction temperature was controlled precisely by an Omega programmable temperature controller. Prior to each experiment, the sample was pretreated at $400{ }^{\circ} \mathrm{C}$ for $0.5 \mathrm{~h}$ in a flow of $20 \mathrm{vol} . \% \mathrm{O}_{2} / \mathrm{N}_{2}$ and then cooled down to $200^{\circ} \mathrm{C}$. The background spectrum was collected in flowing $\mathrm{N}_{2}$ and automatically subtracted from the sample spectrum. The reaction conditions were controlled as follows: $300 \mathrm{ml} / \mathrm{min}$ total flow rate, $500 \mathrm{ppm} \mathrm{NH}_{3}$ or $500 \mathrm{ppm} \mathrm{NO}+5 \mathrm{vol} . \%$ $\mathrm{O}_{2}$, and $\mathrm{N}_{2}$ balance. All spectra were recorded by accumulating 100 scans with a resolution of $4 \mathrm{~cm}^{-1}$.

\section{Results and discussion}

\section{1. $\mathrm{NH}_{3}-\mathrm{SCR}$ activity of different transition metal doped catalysts}

As shown in Fig. $1 \mathrm{~A}$, the $\mathrm{Ce}_{0.2} \mathrm{TiO}_{x}$ catalyst showed more than $90 \% \mathrm{NO}_{x}$ conversion from 250 to $400{ }^{\circ} \mathrm{C}$ under a GHSV of $250,000 \mathrm{~h}^{-1}$. Several transition metals including $\mathrm{W}, \mathrm{Mo}, \mathrm{Fe}, \mathrm{Co}$ and $\mathrm{Cu}$ were doped into the $\mathrm{Ce}_{0.2} \mathrm{TiO}_{x}$ catalyst. The addition of Mo to the Ce-Ti mixed oxide catalyst has no obvious influence on the catalytic activity. Other transition metal (W, Fe, Co and $\mathrm{Cu}$ ) doped catalysts all presented enhanced low temperature SCR activity. However, the medium and high temperature $\mathrm{NO}_{x}$ conversions over $\mathrm{Ce}_{0.2} \mathrm{Co}_{0.1} \mathrm{TiO}_{x}$ and $\mathrm{Ce}_{0.2} \mathrm{Cu}_{0.1} \mathrm{TiO}_{x}$ decreased sharply, and the high temperature $\mathrm{NO}_{x}$ conversion over $\mathrm{Ce}_{0.2} \mathrm{Fe}_{0.1} \mathrm{TiO}_{x}$ decreased significantly. Only $\mathrm{Ce}_{0.2} \mathrm{~W}_{0.1} \mathrm{TiO}_{x}$ clearly showed both enhanced low temperature activity and high temperature activity simultaneously combined with enhanced $\mathrm{N}_{2}$ selectivity (Fig. 1B), compared with those over undoped $\mathrm{Ce}_{0.2} \mathrm{TiO}_{x}$.

\subsection{Influence of $W$ doping molar ratio}

With the increase of $\mathrm{W}$ doping molar ratio from 0.1 to 0.2 , the high temperature $\mathrm{NO}_{x}$ conversion was maintained at $100 \%$ even up to $450^{\circ} \mathrm{C}$, while the low temperature $\mathrm{NO}_{x}$ conversion did not show any decrease (Fig. 2). However, further increasing the relative doping amount of $\mathrm{W}$ to 0.3 and 0.5 resulted in an obvious decline of low temperature SCR activity, although the high temperature $\mathrm{NO}_{x}$ conversions still maintained being 100\%. Therefore, in short summary, the $\mathrm{Ce}_{0.2} \mathrm{~W}_{0.2} \mathrm{TiO}_{x}$ catalyst presented an optimal $\mathrm{NH}_{3}-$ SCR performance with Ce:W molar ratio being $1: 1$.

\subsection{Influence of GHSV and stability test}

The $\mathrm{NO}_{x}$ conversions over $\mathrm{Ce}_{0.2} \mathrm{~W}_{0.2} \mathrm{TiO}_{x}$ catalyst under different GHSV are shown in Fig. 3. Obviously, the increase of GHSV only resulted in some decrease of low temperature SCR activity, but no clear influence on high temperature activity. The catalyst 

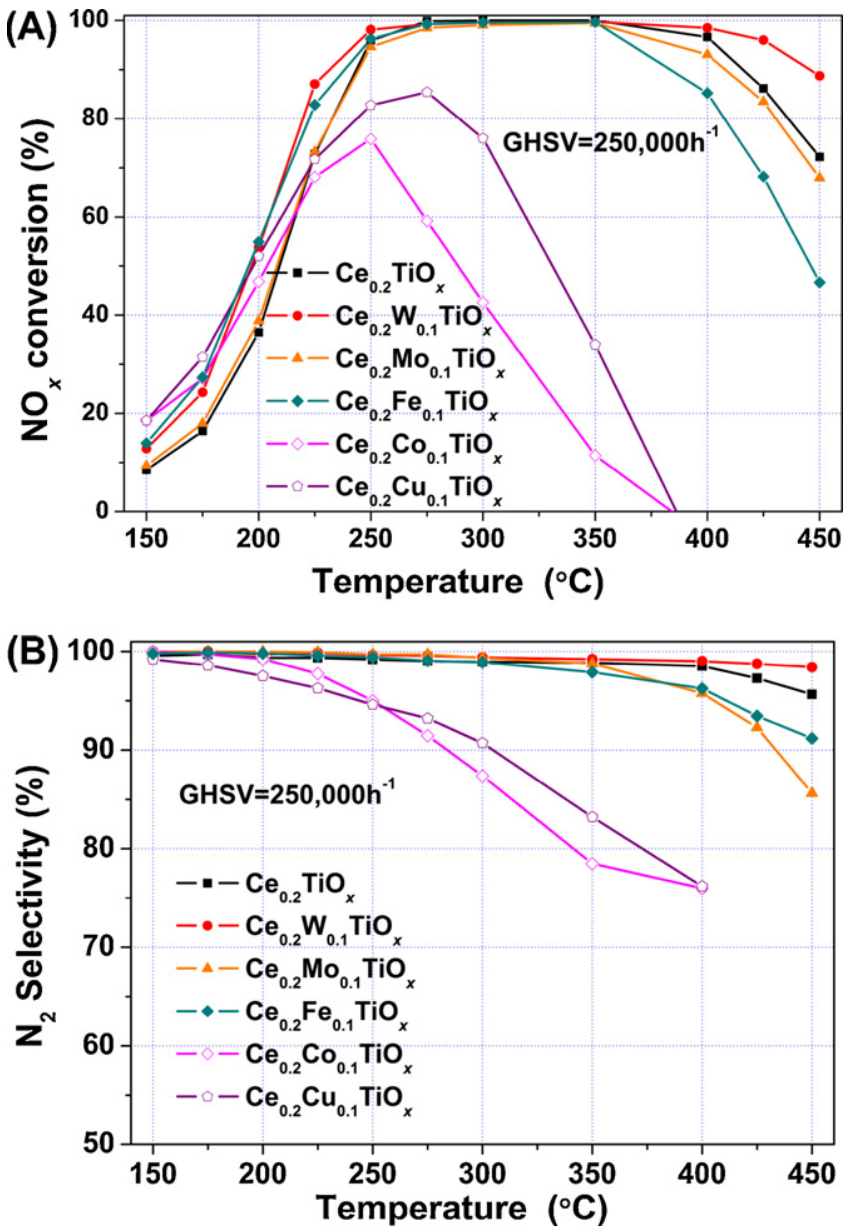

Fig. 1. (A) $\mathrm{NO}_{x}$ conversions and (B) $\mathrm{N}_{2}$ selectivity over $\mathrm{Ce}_{0.2} \mathrm{TiO}_{x}$ and transition metal (W, Mo, Fe, $\mathrm{Co}, \mathrm{Cu}$ ) doped catalysts. Reaction conditions: $[\mathrm{NO}]=\left[\mathrm{NH}_{3}\right]=500 \mathrm{ppm}$, $\left[\mathrm{O}_{2}\right]=5 \mathrm{vol} . \%, \mathrm{~N}_{2}$ balance and GHSV $=250,000 \mathrm{~h}^{-1}$.

even showed over $90 \% \mathrm{NO}_{x}$ conversion in a wide temperature range from 275 to $450^{\circ} \mathrm{C}$ under a rather high GHSV of $500,000 \mathrm{~h}^{-1}$, suggesting that this $\mathrm{Ce}_{0.2} \mathrm{~W}_{0.2} \mathrm{TiO}_{x}$ catalyst is highly resistant to large space velocity, which is very important for its practical use on diesel vehicles with limited space on board.

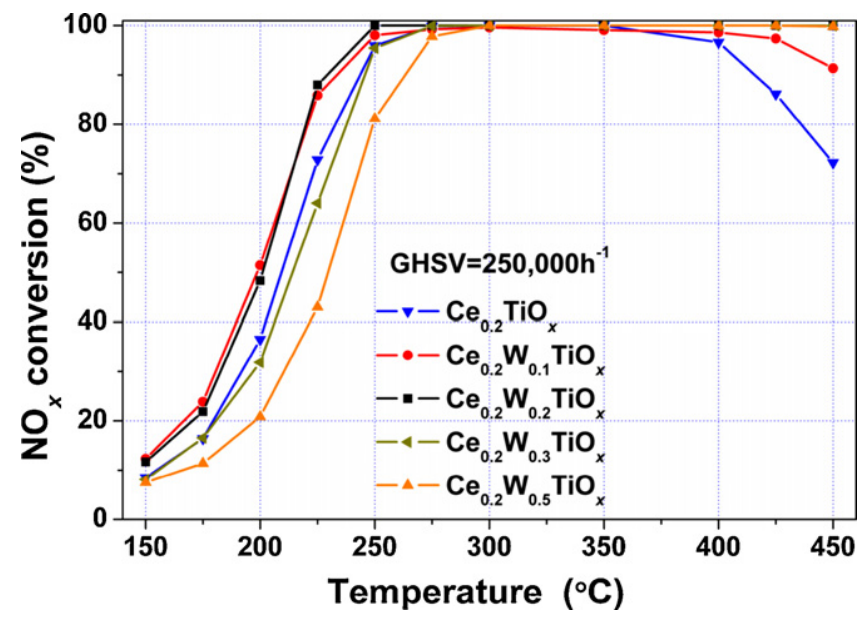

Fig. 2. $\mathrm{NO}_{x}$ conversions over $\mathrm{Ce}_{0.2} \mathrm{~W}_{\mathrm{a}} \mathrm{TiO}_{x}(a=0,0.1,0.2,0.3,0.5)$ catalysts. Reaction conditions: $[\mathrm{NO}]=\left[\mathrm{NH}_{3}\right]=500 \mathrm{ppm},\left[\mathrm{O}_{2}\right]=5 \mathrm{vol} . \%, \mathrm{~N}_{2}$ balance and $\mathrm{GHSV}=250,000 \mathrm{~h}^{-1}$.

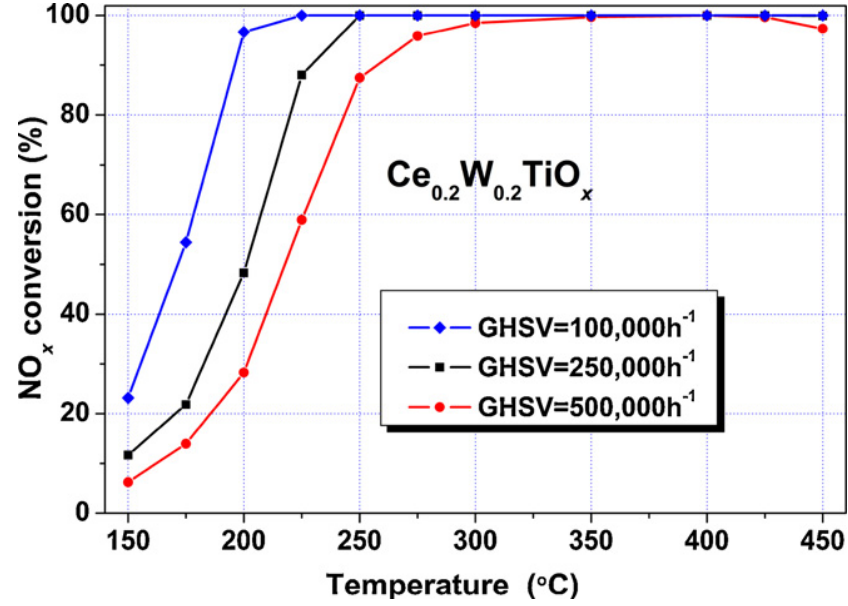

Fig. 3. $\mathrm{NO}_{x}$ conversions over $\mathrm{Ce}_{0.2} \mathrm{~W}_{0.2} \mathrm{TiO}_{x}$ catalyst under different GHSV. Reaction conditions: $[\mathrm{NO}]=\left[\mathrm{NH}_{3}\right]=500 \mathrm{ppm},\left[\mathrm{O}_{2}\right]=5 \mathrm{vol} . \%$ and $\mathrm{N}_{2}$ balance.

The stability of the $\mathrm{Ce}_{0.2} \mathrm{~W}_{0.2} \mathrm{TiO}_{x}$ catalyst was also tested under a GHSV of $250,000 \mathrm{~h}^{-1}$ (Fig. 4). Clearly, there was no deactivation occurred, and the $\mathrm{NO}_{x}$ conversion and $\mathrm{N}_{2}$ selectivity both maintained at $100 \%$ during the tested $100 \mathrm{~h}$ at $300^{\circ} \mathrm{C}$. After the stability test, the $\mathrm{NH}_{3}$-SCR activity of the aged catalyst was tested again, and no change was observed at each temperature point comparing with the activity of fresh catalyst, indicating a high stability of $\mathrm{Ce}_{0.2} \mathrm{~W}_{0.2} \mathrm{TiO}_{x}$.

\subsection{Influence of $\mathrm{CO}_{2}, \mathrm{H}_{2} \mathrm{O}, \mathrm{SO}_{2}$ and $\mathrm{NO}_{2}$}

We also tested the effects of $\mathrm{CO}_{2}, \mathrm{H}_{2} \mathrm{O}, \mathrm{SO}_{2}$ and $\mathrm{NO}_{2}$ on the SCR activity of $\mathrm{Ce}_{0.2} \mathrm{~W}_{0.2} \mathrm{TiO}_{x}$ under a GHSV of $250,000 \mathrm{~h}^{-1}$ (Figs. 5 and 6). The coexistence of 5 vol.\% $\mathrm{H}_{2} \mathrm{O}$ just showed a slight influence on the SCR activity below $250^{\circ} \mathrm{C}$. The inhibiting effect of water on the SCR reaction is a common phenomenon. It is usually explained as an effect of a competition between $\mathrm{H}_{2} \mathrm{O}$ and $\mathrm{NH}_{3} / \mathrm{NO}_{x}$ on the reaction sites or as modification of the structure of active sites, e.g. the transformation of Lewis acid sites into Brønsted acid sites [18,22-25]. The $\mathrm{NO}_{x}$ conversion under the coexistence of 5 vol. $\% \mathrm{CO}_{2}$ and $5 \mathrm{vol} . \% \mathrm{H}_{2} \mathrm{O}$ was almost the same as that with only $5 \mathrm{vol} \% \mathrm{H}_{2} \mathrm{O}$ in the feeding gas, suggesting that no synergistic inhibition effect between $\mathrm{CO}_{2}$ and $\mathrm{H}_{2} \mathrm{O}$ was present on the SCR activity.

In the presence of $100 \mathrm{ppm} \mathrm{SO} \mathrm{S}_{2}$ at $300^{\circ} \mathrm{C}$, there was almost no change of $\mathrm{NO}_{x}$ conversion over the catalyst in $12 \mathrm{~h}$. However,

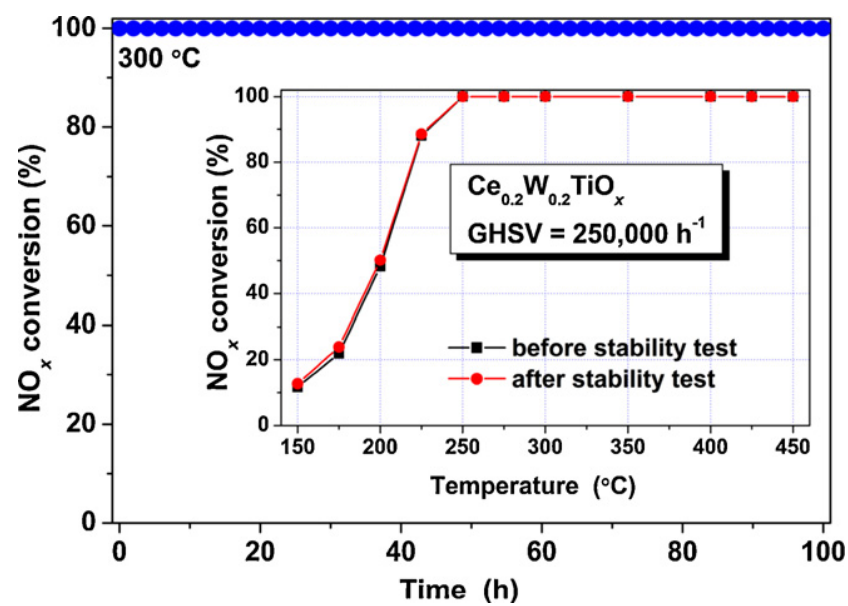

Fig. 4. Stability test result of $\mathrm{Ce}_{0.2} \mathrm{~W}_{0.2} \mathrm{TiO}_{x}$ catalyst. Reaction conditions: $[\mathrm{NO}]=\left[\mathrm{NH}_{3}\right]=500 \mathrm{ppm},\left[\mathrm{O}_{2}\right]=5 \mathrm{vol} . \%, \mathrm{~N}_{2}$ balance and $\mathrm{GHSV}=250,000 \mathrm{~h}^{-1}$. 


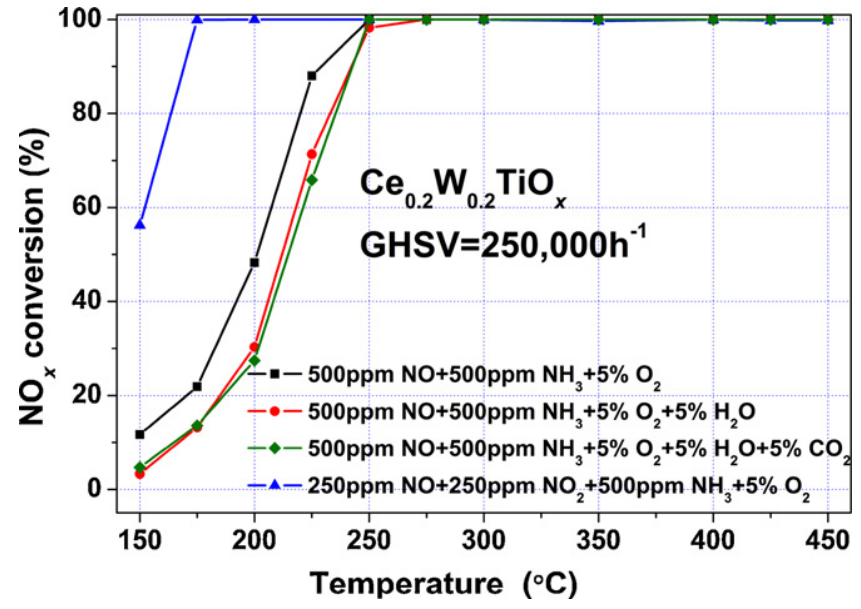

Fig. 5. $\mathrm{NO}_{x}$ conversions over $\mathrm{Ce}_{0.2} \mathrm{~W}_{0.2} \mathrm{TiO}_{x}$ catalyst in the presence of $\mathrm{CO}_{2}, \mathrm{H}_{2} \mathrm{O}$ and $\mathrm{NO}_{2}$. Reaction conditions: $500 \mathrm{ppm} \mathrm{NO}$ (or $250 \mathrm{ppm} \mathrm{NO}$ and $250 \mathrm{ppm} \mathrm{NO}_{2}$ ), $500 \mathrm{ppm}$ $\mathrm{NH}_{3}, 5$ vol.\% $\mathrm{O}_{2}, 5$ vol.\% $\mathrm{CO}_{2}$ (when used), 5 vol.\% $\mathrm{H}_{2} \mathrm{O}$ (when used), $\mathrm{N}_{2}$ balance and $\mathrm{GHSV}=250,000 \mathrm{~h}^{-1}$.

the coexistence of $100 \mathrm{ppm} \mathrm{SO}_{2}$ and $5 \mathrm{vol} . \% \mathrm{H}_{2} \mathrm{O}$ induced a gradually decrease of $\mathrm{NO}_{x}$ conversion at $300{ }^{\circ} \mathrm{C}$ (Fig. 6). After stopping $\mathrm{SO}_{2}+\mathrm{H}_{2} \mathrm{O}$, the $\mathrm{NO}_{x}$ conversion was recovered with a sharp increase from $\mathrm{ca}$. $60 \%$ to $100 \%$. It is speculated that the loss of SCR activity might be mainly associated with the deposit of ammonium sulfate on the catalyst surface [26,27].

When $\mathrm{NO}_{2}$ was added to the feeding gas $\left(\mathrm{NO}_{2}: \mathrm{NO}=1: 1\right)$, the low temperature $\mathrm{NO}_{x}$ conversion over $\mathrm{Ce}_{0.2} \mathrm{~W}_{0.2} \mathrm{TiO}_{x}$ was significantly enhanced due to the "fast SCR" effect, and $100 \% \mathrm{NO}_{x}$ conversion was obtained even in a broad temperature range from 175 to $450^{\circ} \mathrm{C}$.

\subsection{Separated $\mathrm{NO}$ oxidation and $\mathrm{NH}_{3}$ oxidation}

In order to investigate the effects of $\mathrm{W}$ species in $\mathrm{Ce}_{0.2} \mathrm{~W}_{0.2} \mathrm{TiO}_{x}$ catalyst, the separate $\mathrm{NO}$ oxidation $\left(\mathrm{NO}+\mathrm{O}_{2}\right)$ and separate $\mathrm{NH}_{3}$ oxidation $\left(\mathrm{NH}_{3}+\mathrm{O}_{2}\right)$ experiments were also carried out (Fig. 7). The $\mathrm{NO}_{2}$ production in the separate $\mathrm{NO}$ oxidation reaction over $\mathrm{Ce}_{0.2} \mathrm{~W}_{0.2} \mathrm{TiO}_{x}$ is obviously higher than that over $\mathrm{Ce}_{0.2} \mathrm{TiO}_{x}$ in the low temperature range (Fig. 7A). Many studies have shown that, if the SCR catalyst can oxidize $\mathrm{NO}$ to $\mathrm{NO}_{2}$ in situ, its low temperature SCR activity will be significantly enhanced due to the effect of "fast SCR" $[1,21]$. Therefore, the introduction of W could enhance the low

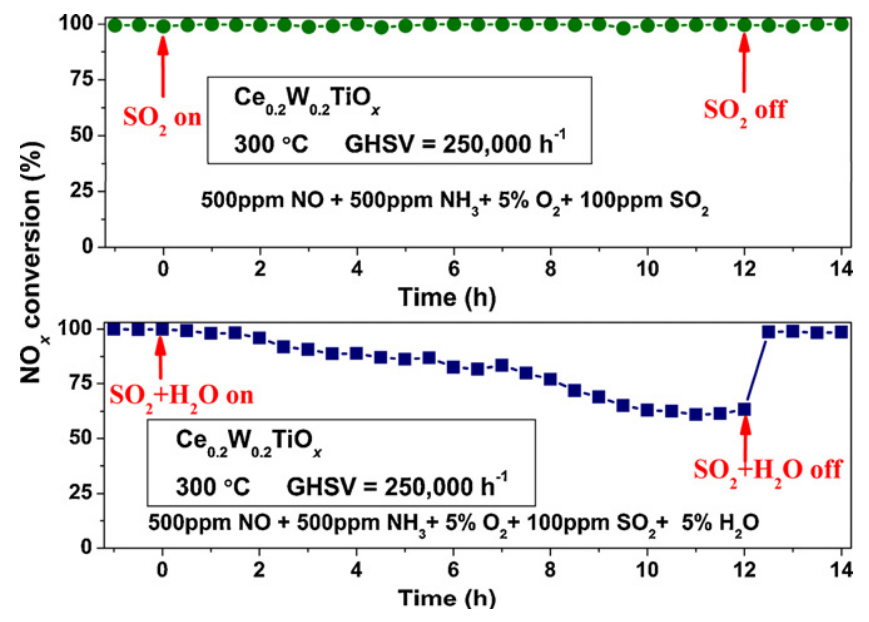

Fig. 6. $\mathrm{NO}_{x}$ conversions over $\mathrm{Ce}_{0.2} \mathrm{~W}_{0.2} \mathrm{TiO}_{x}$ catalyst in the presence of $\mathrm{SO}_{2}$ and $\mathrm{SO}_{2}+\mathrm{H}_{2} \mathrm{O}$ at $300^{\circ} \mathrm{C}$. Reaction conditions: [NO $]=\left[\mathrm{NH}_{3}\right]=500 \mathrm{ppm}$, $\left[\mathrm{O}_{2}\right]=5 \mathrm{vol} . \%, 100 \mathrm{ppm} \mathrm{SO}$ (when used), $5 \mathrm{vol} . \% \mathrm{H}_{2} \mathrm{O}$ (when used), $\mathrm{N}_{2}$ balance and $\mathrm{GHSV}=250,000 \mathrm{~h}^{-1}$.
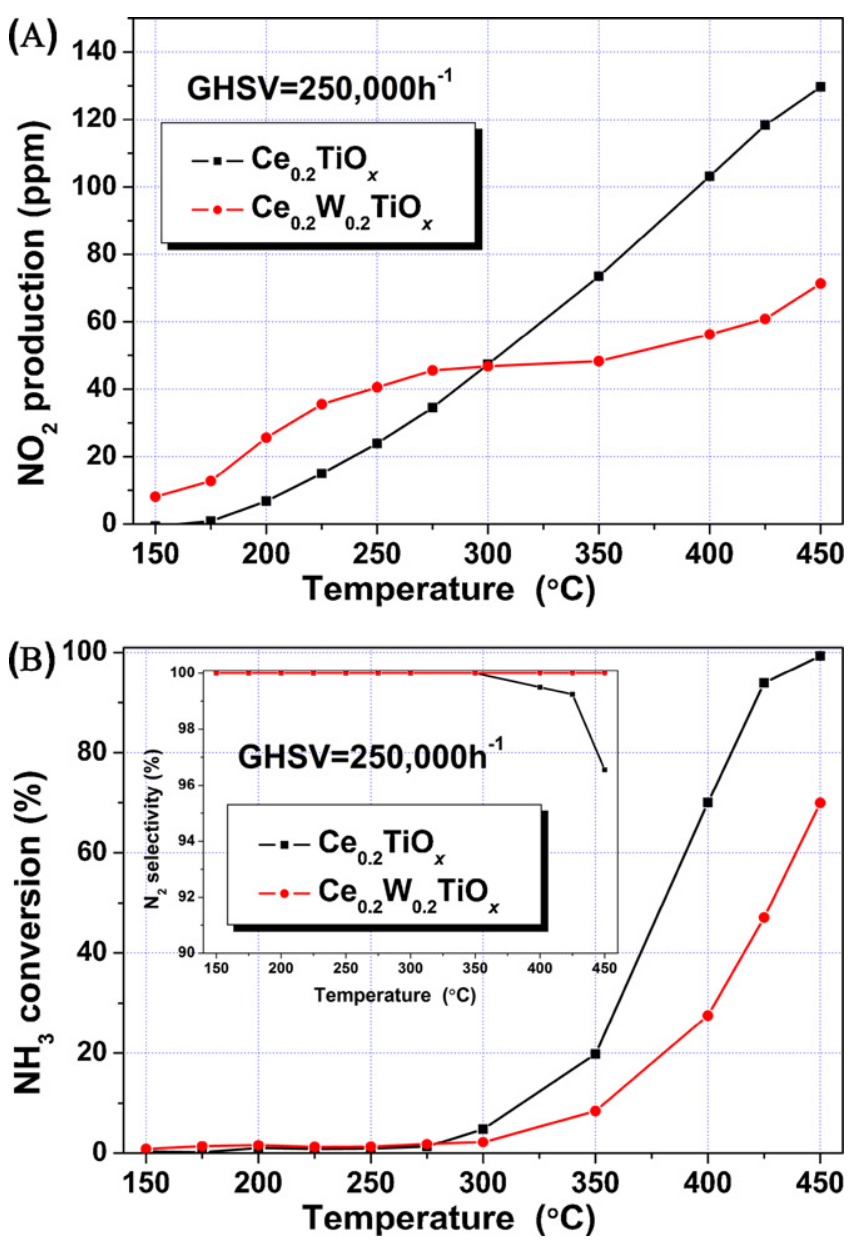

Fig. 7. (A) $\mathrm{NO}_{2}$ productions during separate $\mathrm{NO}$ oxidation reaction and (b) $\mathrm{NH}_{3}$ conversions and $\mathrm{N}_{2}$ selectivity during separate $\mathrm{NH}_{3}$ oxidation reaction over $\mathrm{Ce}_{0.2} \mathrm{TiO}_{x}$ and $\mathrm{Ce}_{0.2} \mathrm{~W}_{0.2} \mathrm{TiO}_{x}$ catalysts. Reaction conditions: (A) [NO] $=500 \mathrm{ppm}$, (B) $\left[\mathrm{NH}_{3}\right]=500 \mathrm{ppm},\left[\mathrm{O}_{2}\right]=5 \mathrm{vol} . \%, \mathrm{~N}_{2}$ balance and $\mathrm{GHSV}=250,000 \mathrm{~h}^{-1}$.

temperature activity of the $\mathrm{Ce}_{0.2} \mathrm{~W}_{0.2} \mathrm{TiO}_{x}$ catalyst by promoting $\mathrm{NO}$ oxidation to $\mathrm{NO}_{2}$ to facilitate the "fast SCR" reaction.

The high temperature $\mathrm{NH}_{3}$ oxidation ability of $\mathrm{Ce}_{0.2} \mathrm{~W}_{0.2} \mathrm{TiO}_{x}$ is obviously lower than that of $\mathrm{Ce}_{0.2} \mathrm{TiO}_{x}$ (Fig. 7B), which means that the addition of $\mathrm{W}$ could inhibit the unselective oxidation of $\mathrm{NH}_{3}$ and thus promote the high temperature activity of $\mathrm{Ce}_{0.2} \mathrm{~W}_{0.2} \mathrm{TiO}_{x}$. Besides, some $\mathrm{NO}, \mathrm{NO}_{2}$ and $\mathrm{N}_{2} \mathrm{O}$ were detected at high temperatures in the $\mathrm{NH}_{3}$ oxidation reaction over $\mathrm{Ce}_{0.2} \mathrm{TiO}_{x}$, while none of these by-products was observed over $\mathrm{Ce}_{0.2} \mathrm{~W}_{0.2} \mathrm{TiO}_{x}$, suggesting that the introduction of $\mathrm{W}$ species into $\mathrm{Ce}_{0.2} \mathrm{~W}_{0.2} \mathrm{TiO}_{x}$ is also beneficial to the enhancement of $\mathrm{N}_{2}$ selectivity in $\mathrm{NH}_{3}-\mathrm{SCR}$ reaction.

A catalytic cycle for the SCR reaction involving both acid and redox reactions was proposed by Topsøe et al. [28,29], and the promotion effects of $\mathrm{W}$ species in $\mathrm{V}_{2} \mathrm{O}_{5}-\mathrm{WO}_{3} / \mathrm{TiO}_{2}$ catalysts were attributed to the increase of both catalyst redox properties and acid sites [25,30-33]. Previous studies by Lietti et al. [25,30,31] have indicated that the catalyst redox functions (especially the reoxidation process of catalytic sites) govern the catalytic reactivity in the low-temperature region, whereas the SCR reaction in the high-temperature region is likely controlled by the surface acid properties. Therefore, in this study, we can expect that the promoted NO oxidation activity at low temperatures $\left(<300^{\circ} \mathrm{C}\right)$ and the inhibited unselective oxidation of $\mathrm{NH}_{3}$ (as well as the decreased NO oxidation) at high temperatures $\left(>300^{\circ} \mathrm{C}\right)$ is strongly associated with the impact of $\mathrm{W}$ addition on the redox and acid properties of $\mathrm{Ce}_{0.2} \mathrm{~W}_{0.2} \mathrm{TiO}_{x}$, respectively. 
Table 1

Surface atomic concentrations and BET surface areas of $\mathrm{Ce}_{0.2} \mathrm{TiO}_{x}$ and $\mathrm{Ce}_{0.2} \mathrm{~W}_{0.2} \mathrm{TiO}_{x}$ catalysts.

\begin{tabular}{llllll}
\hline \multirow{2}{*}{ Sample } & \multicolumn{3}{l}{ Surface atomic concentration ${ }^{\mathrm{a}}(\%)$} & \multirow{2}{*}{ BET surface area $\left(\mathrm{m}^{2} / \mathrm{g}\right)$} \\
\cline { 2 - 5 } & $\mathrm{Ce}$ & $\mathrm{W}$ & $\mathrm{Ti}$ & $\mathrm{O}$ & \\
\hline $\mathrm{Ce}_{0.2} \mathrm{TiO}_{x}$ & 4.6 & - & 19.1 & 76.3 & 125.7 \\
$\mathrm{Ce}_{0.2} \mathrm{~W}_{0.2} \mathrm{TiO}_{x}$ & 6.1 & 4.6 & 16.1 & 73.2 & 107.9 \\
\hline
\end{tabular}

a According to XPS analysis.

\subsection{BET surface area, XRD and Raman spectra}

As shown in Table 1 , the BET surface area of $\mathrm{Ce}_{0.2} \mathrm{~W}_{0.2} \mathrm{TiO}_{x}$ $\left(107.9 \mathrm{~m}^{2} / \mathrm{g}\right)$ is lower than that of $\mathrm{Ce}_{0.2} \mathrm{TiO}_{x}\left(125.7 \mathrm{~m}^{2} / \mathrm{g}\right)$, yet the SCR performance of $\mathrm{Ce}_{0.2} \mathrm{~W}_{0.2} \mathrm{TiO}_{x}$ is actually much higher than that of $\mathrm{Ce}_{0.2} \mathrm{TiO}_{x}$, indicating that some synergistic effect must exist between the Ce and $\mathrm{W}$ species [34].

No Ce or $\mathrm{W}$ species was observed in $\mathrm{Ce}_{0.2} \mathrm{~W}_{0.2} \mathrm{TiO}_{x}$ either in XRD or in Raman analysis (Fig. 8), while only anatase $\mathrm{TiO}_{2}$ was detected. Although the $\mathrm{Ce}-\mathrm{W}$ containing species might already exceed the monolayer dispersion on $\mathrm{TiO}_{2}$, the multi-layer active species probably only contained amorphous phase or crystallite phase with very small particle size (such as $\mathrm{Ce}-\mathrm{W}$ solid solution without long-range order). In such case, it is still reasonable to see no diffraction peaks of $\mathrm{Ce}$ or $\mathrm{W}$ species. In the XRD analysis, a slightly higher crystallization degree of anatase $\mathrm{TiO}_{2}$ in the bulk phase was observed in $\mathrm{Ce}_{0.2} \mathrm{~W}_{0.2} \mathrm{TiO}_{x}$ than that in $\mathrm{Ce}_{0.2} \mathrm{TiO}_{x}$. However, the Raman spectra apparently showed that the introduction of $\mathrm{W}$ species strongly inhibited the crystallization of anatase $\mathrm{TiO}_{2}$ on the catalyst surface, probably leading to a much higher dispersion degree of active $\mathrm{Ce}$ species.

\subsection{XPS results}

It was reported that highly dispersed nano-crystalline $\mathrm{CeO}_{2}$ is the active phase in Ce-Ti mixed oxide catalyst $[16,17,20,21]$. According to the XPS results, there are more surface Ce atoms dispersed on $\mathrm{Ce}_{0.2} \mathrm{~W}_{0.2} \mathrm{TiO}_{x}$ than those on $\mathrm{Ce}_{0.2} \mathrm{TiO}_{x}$ (Table 1 ), which indicate that the introduction of $\mathrm{W}$ could induce more abundant $\mathrm{CeO}_{2}$ crystallite and thus increase the amount of active sites on the catalyst surface. Furthermore, the existence of tungsten species could also contribute to the $\mathrm{NH}_{3}$-SCR reaction by their promotion effects [20,33-35]. In addition, more Ce species dispersed on the surface of $\mathrm{Ce}_{0.2} \mathrm{~W}_{0.2} \mathrm{TiO}_{x}$ will induce a strong inhibition effect on the crystallization of surface $\mathrm{TiO}_{2}$. Contrastively, less Ce species
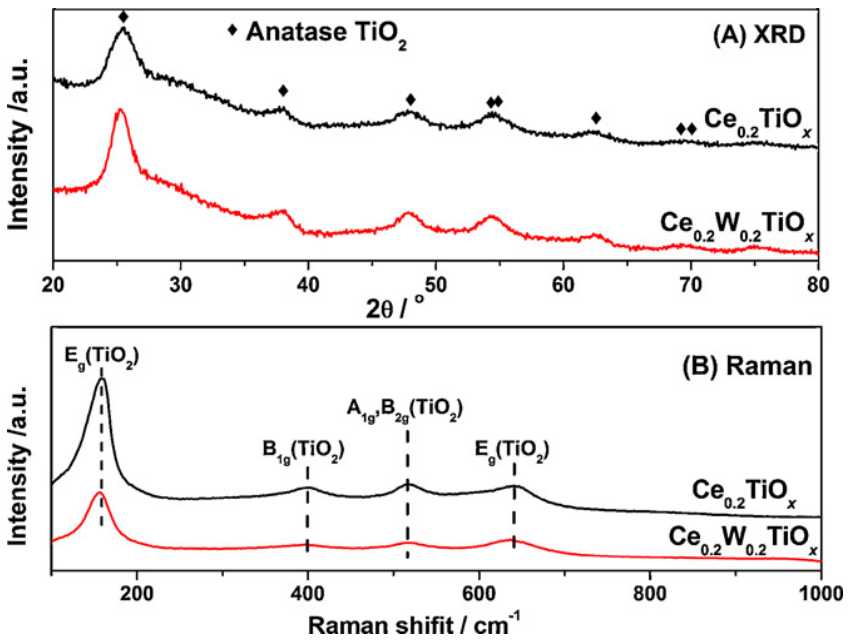

Fig. 8. (A) XRD patterns and (B) Raman spectra $\left(\lambda_{\mathrm{ex}}=532 \mathrm{~nm}\right)$ of $\mathrm{Ce}_{0.2} \mathrm{TiO}_{x}$ and $\mathrm{Ce}_{0.2} \mathrm{~W}_{0.2} \mathrm{TiO}_{x}$ catalysts.

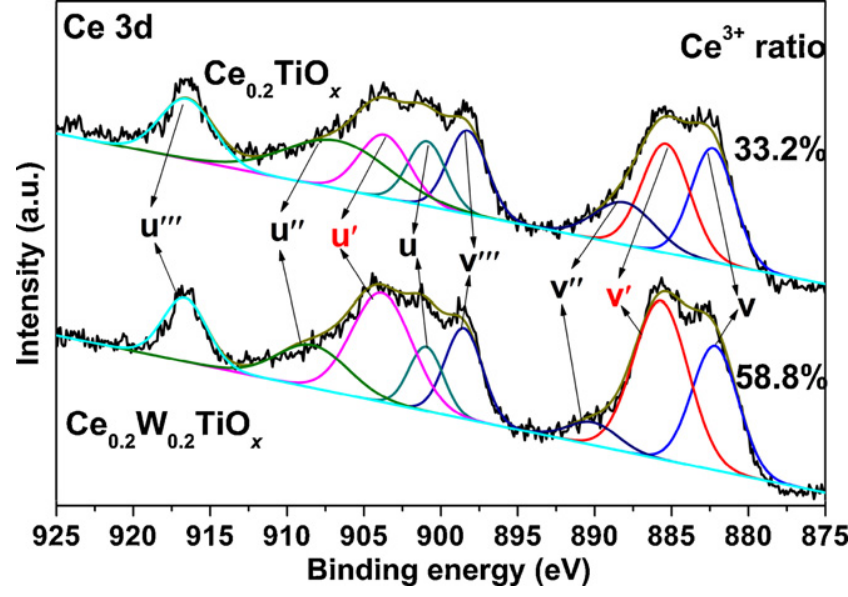

Fig. 9. XPS results of $\mathrm{Ce} 3 \mathrm{~d}$ of $\mathrm{Ce}_{0.2} \mathrm{TiO}_{x}$ and $\mathrm{Ce}_{0.2} \mathrm{~W}_{0.2} \mathrm{TiO}_{x}$ catalysts.

existed in the bulk phase of catalyst will cause a weak inhibition effect on the crystallization of bulk $\mathrm{TiO}_{2}$. This might be an important reason for the contradictory trends of $\mathrm{TiO}_{2}$ crystallization on the surface and in the bulk phase between $\mathrm{Ce}_{0.2} \mathrm{~W}_{0.2} \mathrm{TiO}_{x}$ and $\mathrm{Ce}_{0.2} \mathrm{TiO}_{x}$, as shown by the XRD results and Raman spectra in Fig. 8.

The Ce 3d peaks were fitted by searching for the optimum combination of Gaussian bands with the correlation coefficients $\left(r^{2}\right)$ above 0.99 (Fig. 9). The sub-bands labeled $\mathrm{u}^{\prime}$ and $\mathrm{v}^{\prime}$ represent the $3 \mathrm{~d}^{10} 4 \mathrm{f}^{1}$ initial electronic state corresponding to $\mathrm{Ce}^{3+}$, and the sub-bands labeled $\mathrm{u}, \mathrm{u}^{\prime \prime}, \mathrm{u}^{\prime \prime \prime}, \mathrm{v}, \mathrm{v}^{\prime \prime}$, and $\mathrm{v}^{\prime \prime \prime}$ represent the $3 \mathrm{~d}^{10} 4 \mathrm{f}^{0}$ state of $\mathrm{Ce}^{4+}$. The $\mathrm{Ce}^{3+}$ ratio, calculated by $\mathrm{Ce}^{3+} /\left(\mathrm{Ce}^{3+}+\mathrm{Ce}^{4+}\right)$, of $\mathrm{Ce}_{0.2} \mathrm{~W}_{0.2} \mathrm{TiO}_{x}$ (58.5\%) was significantly higher than that of $\mathrm{Ce}_{0.2} \mathrm{TiO}_{x}$ (33.2\%), indicating the presence of more surface oxygen vacancies on $\mathrm{Ce}_{0.2} \mathrm{~W}_{0.2} \mathrm{TiO}_{x}$.

The $01 \mathrm{~s}$ peak was fitted into two sub-bands by searching for the optimum combination of Gaussian bands with the correlation coefficients $\left(r^{2}\right)$ above 0.99 (Fig. 10). The sub-bands at $529.5-530.0 \mathrm{eV}$ could be attributed to the lattice oxygen $\mathrm{O}^{2-}$ (denoted as $\mathrm{O}_{\beta}$ ). Two shoulder sub-bands at $531.0-531.6 \mathrm{eV}$ and $532.8-533.0 \mathrm{eV}$ are assigned to the surface adsorbed oxygen (denoted as $\mathrm{O}_{\alpha}$ ), such as $\mathrm{O}_{2}{ }^{2-}$ and $\mathrm{O}^{-}$belonging to defect-oxide or hydroxyl-like group, and chemisorbed water (denoted as $\mathrm{O}_{\alpha}{ }^{\prime}$ ), respectively [36,37]. Surface adsorbed oxygen $\left(\mathrm{O}_{\alpha}\right)$ is often thought to be more reactive in oxidation reactions due to its higher mobility than lattice oxygen $\left(\mathrm{O}_{\beta}\right)$, so many researchers considered that high $\mathrm{O}_{\alpha}$ ratio is beneficial for the NO oxidation to $\mathrm{NO}_{2}$ in the $\mathrm{SCR}$ reaction and thereafter facilitate the "fast SCR" reaction [38-40]. Interestingly, in this study the calculated $\mathrm{O}_{\alpha}$ ratio, calculated by $\mathrm{O}_{\alpha} /\left(\mathrm{O}_{\alpha}+\mathrm{O}_{\alpha}{ }^{\prime}+\mathrm{O}_{\beta}\right)$, of

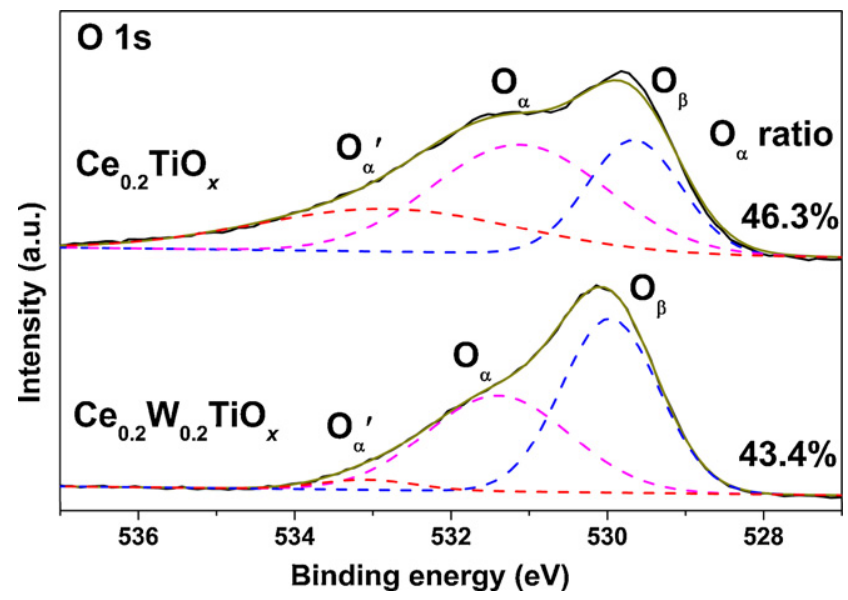

Fig. 10. XPS results of $\mathrm{O} 1 \mathrm{~s}$ of $\mathrm{Ce}_{0.2} \mathrm{TiO}_{x}$ and $\mathrm{Ce}_{0.2} \mathrm{~W}_{0.2} \mathrm{TiO}_{x}$ catalysts. 


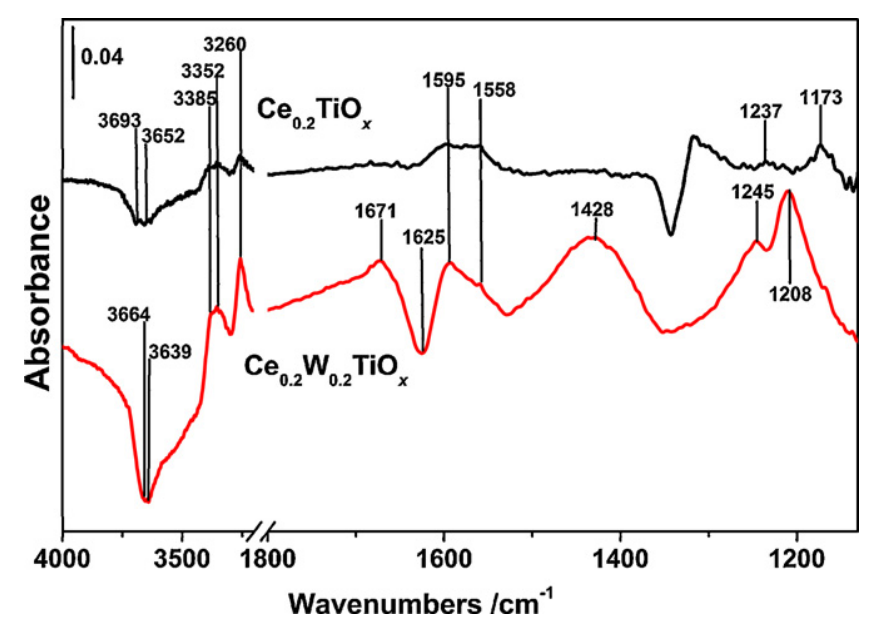

Fig. 11. In situ DRIFTS of $\mathrm{NH}_{3}$ adsorption at $200^{\circ} \mathrm{C}$.

$\mathrm{Ce}_{0.2} \mathrm{~W}_{0.2} \mathrm{TiO}_{x}$ (43.4\%) is slightly lower than that of $\mathrm{Ce}_{0.2} \mathrm{TiO}_{x}$ (46.3\%), which means that some other important changes (such as the increase of active $\mathrm{CeO}_{2}$ crystallite, redox properties, and surface acid sites) but not the changes of $\mathrm{O}_{\alpha}$ ratio induced by $\mathrm{W}$ addition caused the enhancement of low temperature NO oxidation ability of $\mathrm{Ce}_{0.2} \mathrm{~W}_{0.2} \mathrm{TiO}_{x}$. However, the inhibited high temperature oxidation of $\mathrm{NH}_{3}$ over $\mathrm{Ce}_{0.2} \mathrm{~W}_{0.2} \mathrm{TiO}_{x}$ might be associated with the low $\mathrm{O}_{\alpha}$ ratio.

\subsection{In situ DRIFTS}

The in situ DRIFTS of $\mathrm{NH}_{3}$ adsorption at $200^{\circ} \mathrm{C}$ were measured to examine the change of acidity on the catalyst after $\mathrm{W}$ addition (Fig. 11). The bands at $1671 \mathrm{~cm}^{-1}$ and $1428 \mathrm{~cm}^{-1}$ are assigned to the symmetric and asymmetric bending vibrations of ionic $\mathrm{NH}_{4}{ }^{+}$ $[6,28,41]$; the bands at $1595 \mathrm{~cm}^{-1}$ and $1245,1208 / 1237,1173 \mathrm{~cm}^{-1}$ are assigned to the asymmetric and symmetric bending vibrations of coordinated $\mathrm{NH}_{3}$ [42-44]; the band at $1558 \mathrm{~cm}^{-1}$ is assigned to the scissoring vibration mode of $\mathrm{NH}_{2}$ species $[43,45]$; the bands at 3260,3352 and $3385 \mathrm{~cm}^{-1}$ are assigned to the $\mathrm{N}-\mathrm{H}$ stretching vibration modes [6,43]; and the bands at $1625 \mathrm{~cm}^{-1}$ and 3639 , $3664 / 3652,3693 \mathrm{~cm}^{-1}$ are assigned to the hydroxyl consumption due to the interaction with $\mathrm{NH}_{3}$ to form $\mathrm{NH}_{4}^{+}[6,42]$.

After $\mathrm{NH}_{3}$ adsorption, obviously stronger $\mathrm{NH}_{3}$ (1595 and $1208 \mathrm{~cm}^{-1}$ ) and $\mathrm{NH}_{4}{ }^{+}\left(1671\right.$ and $1428 \mathrm{~cm}^{-1}$ ) bands were observed on $\mathrm{Ce}_{0.2} \mathrm{~W}_{0.2} \mathrm{TiO}_{x}$, despite its low surface area, than those on $\mathrm{Ce}_{0.2} \mathrm{TiO}_{x}$, indicating that the introduction of $\mathrm{W}$ species tremendously increased both of the Lewis and Brønsted acid sites on the catalyst. Based on some previous studies, we can speculate that the increased Lewis acid sites are mainly composed of unsaturated $\mathrm{W}^{n+}$ cations, while the increased Brønsted acid sites are mainly composed of $\mathrm{W}-\mathrm{OH}$ sites arising from partially hydrated tungsten species, such as $\mathrm{W}=\mathrm{O}, \mathrm{W}-\mathrm{O}-\mathrm{W}$, and Ce-W-O $[18,35,46,47]$. It is worthy to note that the adsorbed $\mathrm{H}_{2} \mathrm{O}$ on the surface of $\mathrm{Ce}_{0.2} \mathrm{~W}_{0.2} \mathrm{TiO}_{x}$ showed an obvious consumption at $1625 \mathrm{~cm}^{-1}$, and at the same time much more hydroxyl groups were consumed on $\mathrm{Ce}_{0.2} \mathrm{~W}_{0.2} \mathrm{TiO}_{x}$ than those on $\mathrm{Ce}_{0.2} \mathrm{TiO}_{x}$ owing to the interaction with $\mathrm{NH}_{3}$ adsorbed species to form $\mathrm{NH}_{4}{ }^{+}$. This result clearly indicates that $\mathrm{H}_{2} \mathrm{O}$ can be readily activated on the $W$ doped catalyst to form Brønsted acid sites, participating in the $\mathrm{NH}_{3}$ $\mathrm{SCR}$ reaction. When the $\mathrm{Ce}_{0.2} \mathrm{~W}_{0.2} \mathrm{TiO}_{x}$ catalyst was subsequently exposed to $\mathrm{NO}+\mathrm{O}_{2}$ afterwards, all of the $\mathrm{NH}_{4}{ }^{+}$and $\mathrm{NH}_{3}$ bands vanished in $2 \mathrm{~min}$ and some bands ascribed to bridging nitrate (1625 and $\left.1269 \mathrm{~cm}^{-1}\right)$, bidentate nitrate $\left(1603 \mathrm{~cm}^{-1}\right)$ and monodentate nitrate $\left(1581 \mathrm{~cm}^{-1}\right)$ appeared [6,48] (Fig. 12), suggesting that both types of acid sites are involved in $\mathrm{NH}_{3}-\mathrm{SCR}$ reaction. It has been

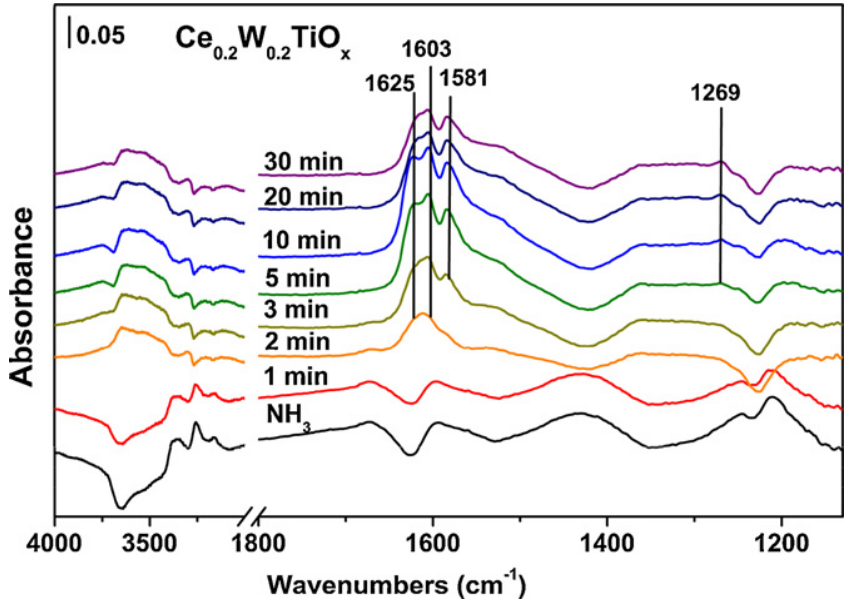

Fig. 12. Pre-adsorbed $\mathrm{NH}_{3}$ species reacted with $\mathrm{NO}+\mathrm{O}_{2}$ over $\mathrm{Ce}_{0.2} \mathrm{~W}_{0.2} \mathrm{TiO}_{x}$ catalyst.

indicated that surface acidity plays an important role in the adsorption and activation of $\mathrm{NH}_{3}$, and thus affects the occurrence of SCR reaction, especially at high temperature range $[31,35]$. Therefore, the increased Brønsted and Lewis acid sites by W addition should be an important reason for the enhanced catalytic activity, especially high temperature activity.

\section{Conclusions}

Several transition metals including $\mathrm{W}, \mathrm{Mo}, \mathrm{Fe}, \mathrm{Co}$ and $\mathrm{Cu}$ were doped into the $\mathrm{Ce}_{0.2} \mathrm{TiO}_{x}$ catalyst prepared by a facile homogeneous precipitation method. Among the doped catalysts, $\mathrm{Ce}_{0.2} \mathrm{~W}_{0.2} \mathrm{TiO}_{x}$ with Ce: $\mathrm{W}$ molar ratio being $1: 1$ showed excellent $\mathrm{NH}_{3}-\mathrm{SCR}$ activity and $100 \% \mathrm{~N}_{2}$ selectivity in a broad temperature range. Besides, the $\mathrm{Ce}_{0.2} \mathrm{~W}_{0.2} \mathrm{TiO}_{x}$ catalyst even showed over $90 \% \mathrm{NO}_{x}$ conversion in a wide temperature range from 275 to $450^{\circ} \mathrm{C}$ under a rather high GHSV of $500,000 \mathrm{~h}^{-1}$, suggesting that this $\mathrm{Ce}_{0.2} \mathrm{~W}_{0.2} \mathrm{TiO}_{x}$ catalyst is highly resistant to large space velocity, which is advantageous to the application for diesel engines with limited installing space for exhaust after-treatment systems.

Although the BET surface area of $\mathrm{Ce}_{0.2} \mathrm{~W}_{0.2} \mathrm{TiO}_{x}$ was lower than that of $\mathrm{Ce}_{0.2} \mathrm{TiO}_{x}$, the introduction of $\mathrm{W}$ species could lead to a much higher dispersion degree of active Ce species and increase the amount of active $\mathrm{CeO}_{2}$ crystallite, oxygen vacancies, and both Brønsted and Lewis acid sites on the catalyst. Furthermore, the low temperature activity of $\mathrm{NO}$ oxidation to $\mathrm{NO}_{2}$ was promoted by $\mathrm{W}$ addition and the high temperature activity of $\mathrm{NH}_{3}$ unselective oxidation was inhibited, which are beneficial to improve the $\mathrm{NH}_{3}$-SCR activity in the whole temperature range and enhance the $\mathrm{N}_{2}$ selectivity in the high temperature range simultaneously.

\section{Acknowledgments}

This work was financially supported by the National Natural Science Foundation of China (50921064, 51108446), the National Basic Research Program of China (2010CB732304), the National High Technology Research and Development Program of China (2009AA064802, 2010AA065003), the Shanghai Tongji Gao Tingyao Environmental Science \& Technology Development Foundation (STGEF) and the Special Co-construction Project of Beijing Municipal Commission of Education.

\section{References}

[1] P. Granger, V.I. Parvulescu, Chem. Rev. 111 (2011) 3155.

[2] Z. Liu, S.I. Woo, Catal. Rev. 48 (2006) 43.

[3] S. Roy, M.S. Hegde, G. Madras, Appl. Energy 86 (2009) 2283. 
[4] F. Liu, H. He, C. Zhang, Chem. Commun. (2008) 2043.

[5] Z. Si, D. Weng, X. Wu, J. Li, G. Li, J. Catal. 271 (2010) 43.

[6] F. Liu, H. He, Y. Ding, C. Zhang, Appl. Catal. B93 (2009) 194.

[7] Y. Li, H. Cheng, D. Li, Y. Qin, Y. Xie, S. Wang, Chem. Commun. (2008) 1470.

[8] S. Brandenberger, O. Kröcher, A. Tissler, R. Althoff, Catal. Rev. 50 (2008) 492.

[9] R.Q. Long, R.T. Yang, J. Am. Chem. Soc. 121 (1999) 5595.

[10] A. Ma, W. Grünert, Chem. Commun. (1999) 71.

[11] G. Carja, G. Delahay, C. Signorile, B. Coq, Chem. Commun. (2004) 1404.

[12] J.H. Park, H.J. Park, J.H. Baik, I.S. Nam, C.H. Shin, J.H. Lee, B.K. Cho, S.H. Oh, J. Catal. 240 (2006) 47.

[13] J.H. Kwak, R.G. Tonkyn, D.H. Kim, J. Szanyi, C.H.F. Peden, J. Catal. 275 (2010) 187

[14] D.W. Fickel, E. D’Addio, J.A. Lauterbach, R.F. Lobo, Appl. Catal. B 102 (2011) 441.

[15] L. Ren, L. Zhu, C. Yang, Y. Chen, Q. Sun, H. Zhang, C. Li, F. Nawaz, X. Meng, F. Xiao, Chem. Commun. 47 (2011) 9789.

[16] W. Xu, Y. Yu, C. Zhang, H. He, Catal. Commun. 9 (2008) 1453.

[17] X. Gao, Y. Jiang, Y. Fu, Y. Zhong, Z. Luo, K. Cen, Catal. Commun. 11 (2010) 465

[18] G. Busca, L. Lietti, G. Ramis, F. Berti, Appl. Catal. B 18 (1998) 1.

[19] V.I. Pârvulescu, P. Grange, B. Delmon, Catal. Today 46 (1998) 233.

[20] L. Chen, J. Li, M. Ge, R. Zhu, Catal. Today 153 (2010) 77.

[21] W. Shan, F. Liu, H. He, X. Shi, C. Zhang, ChemCatChem 3 (2011) 1286

[22] F. Liu, H. He, Catal. Today 153 (2010) 70.

[23] M.D. Amiridis, I.E. Wachs, G. Deo, J.M. Jehng, D.S. Kimy, J. Catal. 161 (1996) 247.

[24] R. Willi, B. Roduit, R.A. Koeppel, A. Wokaun, A. Baiker, Chem. Eng. Sci. 51 (1996) 2897.

[25] L. Lietti, I. Nova, P. Forzatti, Top. Catal. 11/12 (2000) 111.

[26] F. Liu, K. Asakura, H. He, W. Shan, X. Shi, C. Zhang, Appl. Catal. B 103 (2011) 369.

[27] W. Xu, H. He, Y. Yu, J. Phys. Chem. C 113 (2009) 4426.
[28] N.Y. Topsøe, Science 265 (1994) 1217.

[29] N.Y. Topsøe, J.A. Dumesic, H. Topsøe, J. Catal. 151 (1995) 241.

[30] L. Lietti, P. Forzatti, F. Bregani, Ind. Eng. Chem. Res. 35 (1996) 3884.

[31] L. Lietti, P. Forzatti, F. Berti, Catal. Lett. 41 (1996) 35.

[32] I.E. Wachs, G. Deo, B.M. Weckhuysen, A. Andreini, M.A. Vuurman, M. de Boer, M.D. Amiridisz, J. Catal. 161 (1996) 211.

[33] J.P. Chen, R.T. Yang, Appl. Catal. A 80 (1992) 135.

[34] W. Shan, F. Liu, H. He, X. Shi, C. Zhang, Chem. Commun. 47 (2011) 8046.

[35] L. Alemany, L. Lietti, N. Ferlazzo, P. Forzatti, G. Busca, E. Giamello, F. Bregani, J. Catal. 155 (1995) 117.

[36] J.C. Dupin, D. Gonbeau, P. Vinatier, A. Levasseur, Phys. Chem. Chem. Phys. 2 (2000) 1319

[37] J. Fang, X. Bi, D. Si, Z. Jiang, W. Huang, Appl. Surf. Sci. 253 (2007) 8952

[38] L. Chen, J. Li, M. Ge, J. Phys. Chem. C 113 (2009) 21177.

[39] Z. Wu, R. Jin, Y. Liu, H. Wang, Catal. Commun. 9 (2008) 2217.

[40] M. Kang, E.D. Park, J.M. Kim, J.E. Yie, Appl. Catal. A 327 (2007) 261

[41] P.G. Smirniotis, D.A. Peña, B.S. Uphade, Angew. Chem. Int. Ed. 40 (2001) 2479

[42] L. Chen, J. Li, M. Ge, Environ. Sci. Technol. 44 (2010) 9590.

[43] Z. Wu, B. Jiang, Y. Liu, H. Wang, R. Jin, Environ. Sci. Technol. 41 (2007) 5812.

[44] W.S. Kijlstra, D.S. Brands, H.I. Smit, E.K. Poels, A. Bliek, J. Catal. 171 (1997) 208.

[45] G. Qi, R.T. Yang, R. Chang, Appl. Catal. B 93 (2004) 93.

[46] A.S. Mamede, E. Payen, P. Grange, G. Poncelet, A. Ion, M. Alifanti, V.I. Pârvulescu, J. Catal. 223 (2004) 1

[47] M. Kobayashi, K. Miyoshi, Appl. Catal. B 72 (2007) 253.

[48] F. Liu, H. He, C. Zhang, Z. Feng, L. Zheng, Y. Xie, T. Hu, Appl. Catal. B 96 (2010) 408 